\title{
EFL Undergraduate Students' Perspectives of the Curriculum Employed in the English Language Department at the Hashemite University
}

\author{
Malak M. Shehadeh \\ Jordan International schools, P.O box 188, Amman 11821 , Jordan \\ Mohammed M. Obeidat \\ Faculty of Educational Sciences, The Hashemite University, P.O box 330127, Zarqa 13133, Jordan
}

\begin{abstract}
This current study aimed to investigate EFL undergraduate students' perspectives of the curriculum employed in the English Language Department at the Hashemite University. More specifically, the study attempted to explore their perspectives of the literature, linguistics, translation and the four language skills courses they had during their study at the university. The research instruments used was a questionnaire and questionnaire interview. One hundred and seventy seven students ( 40 males and 137 females) took part in the study. Eighty two of them were in the third year of study and 95 were in the fourth. Results showed that the students perceived the curriculum positively and regarded the translation and four language skills courses as the most beneficial. Results also indicated the reasons behind which the students regarded each course as more/less beneficial. In addition, they revealed statistical significant differences in the students' responses due to gender in favor of females and no significant differences according to study-year. In light of these results, recommendations were suggested.
\end{abstract}

Keywords: EFL undergraduates, perspectives, EFL curriculum, EFL courses, The Hashemite University

DOI: $10.7176 / \mathrm{JEP} / 10-26-01$

Publication date:September $30^{\text {th }} 2019$

\section{Introduction}

Some students want to study English or another foreign language for advancement in their professional lives or for getting a better job. English has a special position here since it has become the international language of communication. Some language students find themselves living in a target language community either temporarily or permanently (Ahmed, 2015). English has also become a medium of instruction at universities in a large number of countries, a basic means of second language learning/teaching, and an accessing source of modern knowledge and scientific research (Abdulhafidh, 2015). This speedy growth in the importance of English language has made teaching this language more important and more challenging and has encouraged researchers to be interested in English language curricula.

However, any curriculum including the English as a foreign language (EFL) one comprises the philosophy, purposes, design and implementation of a whole program. It can be conceptualized as a list of subjects for a course to the perception of the ultimate goal of education as a whole. Curriculum is regarded as "the grasp of the basic notions education involves as well as the structural organization every author states within this definition" (Moreno, 2000: 11). It can also be defined as an educational program which states: (i) The educational purpose. (ii) The content teaching procedures and learning experience which will be necessary to achieve this purpose. (iii) Some means for assessing whether the educational ends have been achieved (Bygate, Swein, \& Skehan, 2013). It is argued that curriculum deals with the abstract general goals of education which reflect the overall educational and cultural philosophy of a country, the national and political trends, and the theoretical orientation to language and language learning (Karavas, 2014).

Despite the importance of curriculum in any educational setting, there is a lack of curriculum effectiveness research at the university level. Rezvani and Vakilinejad (2015) state that there is a need for more studies on curricular effectiveness. In this regard, the present study attempts to explore students' perspectives of the EFL curriculum employed in the English Language Department at the Hashemite University. This curriculum includes four majors types, including literature, linguistics, translation, and the four language skills.

With regard to literature and its importance of teaching for EFL undergraduate learners, Tompkins (1993) states that it is a good resource of vocabulary and sentence patterns which would be useful for language learning in the four language skills, listening, reading, writing, and speaking. Zapata (2005) argues that literature is one of the most precious human cultural heritages and many people describe it as a mirror of life. It reflects the identity and value of people in each country. Thus, reading literature is a great way to learn about people's thoughts and culture of another country. The researcher adds that most people discover that reading literature can lead them into a new world where they can experience a variety of people's lives as well as help them to understand themselves and the human condition. The foundation concept of literal arts education is to provide students with 
essential general knowledge; to develop intellectual capacity and critical thinking skills as well as to inculcate leadership and citizenship (Taylor, 2009). Realizing its significance, the literature course is normally integrated into the English language curriculum as an essential requirement which every English major student needs to study. Literature is regarded as a source of meaningful language input and as a tool for motivating the learning of a foreign language in its context (Al Darwish \& Shuqair, 2015). Literature is also invaluable in teaching the student how to think originally. Whether the literature is realistic, naturalistic, comedy, surrealistic, or any of myriad other forms it can take. It helps the student sees patterns, structures, connections and truths that had been hidden in the literal world, disguised by the horror of evil or the horror of banality (White, 2018).

As for linguistics, universities offer linguistic courses since linguistics is concerned with the nature of language and communication. It deals both with a study of particular languages, and the search for general properties common to all languages or large groups of languages. It includes phonetics which investigates the physical realization of speech and phonology which studies the grammatical system speakers use to represent language in the real world. It also includes morphology which explores how linguistic units are combined and syntax which studies how units including words and phrases are combined into sentences. In addition, linguistics comprises semantics which studies how language conveys meaning and pragmatics which investigates language in use (the meaning raised from language occurring in context). (https://linguistics.arizona.edu/content/whatlinguistics-and-why-study-it-0)

It is argued that linguistics helps in developing students' reading comprehension (Loreto, 2007) and plays an important role in the grammatical construction and in comprehending the sides which are required to acquire language proficiency (Hassoon, 2014). Syarif (2016) states that linguistics as the scientific study of language has very crucial role in running instruction. Changes in language teaching-learning method reflect the development of linguistic theories. Webb (2018) identified five benefits for linguistic learning, which are: helping learners to learn something new, improving communicative skills, improving critical thinking and analytical skills, and innovating or conveying meanings in speech and writing.

With respect to translation, Pan (2014) argues that translation should be an integral part of any EFL curriculum. Through the translation course, bachelor students are expected to gain mastery of the components of a foreign language and to apply knowledge to advanced skills in translation and interpretation. The courses that may be offered in an EFL program are: advanced translation, linguistics, special texts, terminology, oral expression, and translation and media. The skills acquired through this program include the use of computer tools in translation tasks, translation of general texts and translation of specialized texts. Calis and Dikilitas (2012) state that translation as a learning practice is favored by learners as it promotes different aspects of learning. This is probably because learners confirm that grammatical patterns in EFL with the equivalent ones in L2. However, the relationship between language learning and translation seems mutually rewording. The more proficient learners become in the language, the more competent they are likely to be translating. On the other hand, translation can also be used to gain proficiency in a language so as to be a more competent user of that language (Artar, 2017).

For the teaching of English to be successful, the four skills, listening, speaking, reading and writing should be integrated in an effective way. These skills should be addressed in a way that helps students meet the standards you set for them for developing their communicative competence gradually. Regarding the oral skills (i.e. listening and speaking), proficiency in them is seen as a desirable goal for EFL School and university learners to the point of equating inability in the use of English to disability. A better knowledge of modern languages will facilitate communication and interaction among people and will promote mobility and mutual understanding (Alonso, 2013). In addition to mobility and mutual understanding, the oral skills aid learners of English through the different stages of study to communicate for a better future career and social stability (Prew, 2014). These two skills are highly interrelated and work simultaneously in real-life situations. So, their integration helps foster effective oral communication (Sadiku, 2015). In terms of reading and writing, they are also integrated with each other since reading intensively leads to professional writing. For example, Zhao and Hiravela (2015) argue that L2 writing courses tend to place a particular emphasis on the idea of reading for writing. Alqouran and Smadi (2016) state that writing is one of the main academic skills that undergraduate students need in pursuing their academic disciplines. Many researchers emphasize the importance of integrating reading with writing as the two skills involve similar cognitive processes.

\subsection{The EFL Curriculum at the University}

The English Language Department in the Hashemite University has stated the aims of each of the five courses encompassed in the Curriculum. These courses are associated with, literature, linguistics, translation, and the four language skills. What follows is the description of the aims of each course.

Literature: Literature courses aim to provide the students with literary samples from various eras such as novels and poetry. These samples should be studied critically and analytically. They also aim to provide students with the fundamental structure of drama. 
Linguistics: Linguistics courses include: theoretical linguistics, applied linguistics, psycholinguistics and sociolinguistics. Theoretical linguistics aims to acquaint the students with theories related to the universal aspects of language and applied linguistics aims to relate linguistics with language teaching, whereas psycholinguistics aims to familiarize the students with the relationship between linguistics and psychological behavior. In addition, sociolinguistics aims to acquaint the students with the interrelationship between language and social structure and to transcribe speech at the phonemic and phonetic levels.

Translation: Translation courses aim to enable students to translate Arabic texts into English and vice versa. They also aim to point out the cultural and linguistic differences between the two languages to draw their attention to the difficulties facing the translator.

The four language skills: These courses include ones related to the oral skills and others associated with the academic skills. With regard to the oral skills courses, they aim at drilling, summarizing, responding and notes taking. They also aim to enable students to listen comprehensively during lectures. And finally, they aim to increase students' listening and speaking capabilities. As for the academic skills courses, they aim to enable students to summarize the main idea of each topic and to develop their thinking skills and critical reading. They also aim to enable them to read critically by asking questions about the text, by evaluating ideas and by recognizing assumptions and implications. In addition, they aim to develop students' fluency and writing productivity using frequent writing exercises, critical reading and enriching vocabulary. And finally, they aim to enable students to do activities concerned with writing.

\subsection{Study Aims}

This current study mainly aimed at investigating the attitudes of 177 EFL undergraduate students' attitudes toward the curriculum used by the English Language Department at the Hashemite University. More specifically, the study attempted to answer the following questions:

1. How do the students perceive each course implemented in the English Language Department and the EFL curriculum as a whole?

2. What are the major reasons which cause the students to perceive each course more/ less useful or beneficial?

3. Are there any statistical significant differences $(\boldsymbol{\sigma}=\mathbf{. 0 5})$ between the means of students' responses due to gender?

4. Are there any statistical significant differences $(\boldsymbol{\sigma}=\mathbf{. 0 5})$ between the means of students' responses due to study year $\left(3^{\text {rd }}\right.$, and $4^{\text {th }}$. years $)$ ?

\section{Literature Review}

This section discusses the available literature related to the aim of the study. That is, it discusses the studies done on EFL students' perspectives of literature, linguistics, translation and the four language skills.

\subsection{Studies related to literature}

Many studies were done on EFL students' attitudes towards the literature courses they attended at the university. The majority of the students were in favor of these courses as they enhanced their cultural awareness, enriched their language in general, developed their skills in the target language, and improved their linguistic competence.

Coskun \& Ogeyik (2007) conducted a study with 72 third- and fourth-year EFL university students to gauge their attitudes towards literature teaching and literature courses. The data were collected through a 5-Likert type scale designed for the present study with 20 items and 5 options used for the percentile values. Results showed that the students were in favor of literature teaching as it enhanced their cultural competence, enriched their language and increased their individual creativity. Cirakli \& Kilickaya (2011) found similar results in this regard. That is, they found that the students had positive attitudes towards literature in a study done with 30 Turkish EFL senior students (i.e., pre-service teachers). The Findings revealed that the students recognized the importance of literature courses in general.

Some researchers found that literature improves the students' four language skills in general and the oral skills in particular. For example, Babaee \& Yahya (2014) did a study with 62 EFL B.A. students chosen randomly from the population of the study. The study aimed to consider literature as a significant tool for teaching fundamental language skills including speaking, listening, reading and writing. A questionnaire of 25 closed items and of several open-end questions were distributed to the participants. Results revealed that all forms of literature were regarded by the students as a tool for developing the four language skills. However, Darwish \& Shuqair (2015) found that EFL students in Kuwait perceived the literature courses they attended as ineffective in improving their oral skills and effective in improving their linguistic competence.

Alfauzan \& Hussain (2017) obtained positive attitudes towards literature in a study which investigated 59 Saudi undergraduate students' perspectives of English literature courses as a part of their B.A. Questionnaires were used to collect quantitative data and retrospective essays were used for qualitative data. Results revealed that the participants thought that these courses improved their competence in the English language. 
Some studies highlighted the importance of the learner's social environment and of the kind of topics chosen for teaching. For example, Tevdovska (2016) executed a survey study with 53 non-native students of English language and literature and whose future career was teaching English as a second or foreign language. The purpose was to explore students' attitudes towards the impact of literary texts on language learning and teaching. The survey was presented in a form of Likert scale and included 20 different statements. The analysis of the findings indicated that the majority of language learners preferred prose to poetry texts. They also indicated that topics relevant to students to students increased their interest and engagement. towards the literature course. The study suggested that the learners' social environment (friends, classmates, family) significantly contributed to constructing positive attitudes and enhancing their perceptions towards literature as medium of learning L2.

In general, students' attitudes change as a result of taking literature courses. This result was obtained by AlMahrooqi \& Al-Wahaibi (2012) who did a study with 34 participants (28 students and 6 teachers) to investigate English majors' attitudes towards literature courses at a higher education institution in Oman.

\subsection{Studies related to linguistics}

Many studies were carried out on linguistics. Some of them focused on its benefits, some focused on the methods used in teaching it, and others highlighted the difficulties of learning it.

With regard to benefit, Al Ghazo \& Al Ghazo (2007), conducted a study with 141 students (88 males and 53 females) to explore the effect of text's linguistics complexity on reading comprehension. Two passages were selected (simple and complicated). At first, Students were asked to read the simple text and answer 10 questions. Two weeks later, they were required to read the more complex text and answer questions. Results of the study showed that linguistics complexity of a text affected reading comprehension. Al Fallaj (2013) also did a study in this regard with 67 Saudi students to explore the importance of linguistics in overcoming the students' problems in pronunciation. A questionnaire was developed for the purpose of the study and then distributed to the sample. Results indicated that teachers with background knowledge of linguistics would be capable of helping their students overcome most of their pronunciation problems. In addition, Hassoon (2014) investigated the importance of cognitive linguistics in learning English. According to the ideas that had been discussed in the study, it could be inferred that linguistics normally plays an important role in the grammatical construction of language and in comprehending the sides which are required to acquire language proficiency.

As for the methods used for teaching linguistics, Belgrave \& Jules (2015) explored an undergraduate student-centered program in linguistics. Qualitative data were gathered from a questionnaire and from a purposive sample within level 2 and 3 of the linguistic program at the UWI Cave Hill Campus which provided a description of students' orientation towards research. There was also analysis of students' perceptions of the extent to which the course content addressed their needs and catered to their success in life beyond the classroom. Results revealed that greater focus on student-centered principles of best practice in the courses' component would enhance the worth and usefulness within broader world context. Another study was done by Koban \& Koc (2016) with 71 EFL university students to analyze their perceptions of blog use in a linguistic course offered in an English Language Teaching program at one of the largest government universities in Turkey. At the end of the semester, the researcher administered a questionnaire consisting of 16 questions about the usage of blog and its contribution to their learning. Results of the study showed that in class lessons were less effective than blog usage with regard to self-learning, self-expression and understanding.

In terms of difficulty, Al-khatib (2013) did a study whose concern was identifying the areas of difficulties that EFL learners from Arabic background face when learning English. The study traced correlation between proficiency and language performance in an attempt to examine whether universal linguistic fundamentals could contribute to the interpretation of language learning in foreign language contexts. The study was comprised of two stages. A pilot sample of 169 students was followed for a six month period in an intensive English program to identify the weaknesses the learners experienced at three contemporary levels. In the second stage, a large sample of 1011 students was studied for a period of one year to determine the cause of difficulties and explore whether universal linguistic fundamentals could contribute to EFL learning. The findings identified three main areas where learners experienced difficulties in learning English. Areas that relate to the linguistic ambiguities of the target language; areas that relate to the prominence of features in the first language; and areas that relate to the competency levels of the learner.

\subsection{Studies related to translation}

There were many studies done on translation. Some of them were conducted on students' needs and perceptions and others were carried out on the effectiveness of translation in learning English as a foreign language.

In terms of students' needs and perceptions, Karoly (2011) carried out a study with 10 first-year Hungarian students who had not taken any translation course before. The aims were to explore students' needs, to capture their perceptions about the translation process and translation competence, and to compare these with the tutors' 
expectations and assumptions as well as with the current course syllabus. Data was collected through questionnaires with the students and a semi-structured interview with their teacher. Results showed that undergraduate students' needs and perceptions were different from the tutors' assumptions and the aims of the course as expressed in the syllabus. Therefore, exploring undergraduate students' actual needs was a crucial step design. Siregar (2018) also did a study with 59 undergraduate students' perception on the current EFL learning in classroom and their perception on translation as useful tool in language learning. The students' perception was collected by online-questionnaire via Google Forms. The questionnaire comprised of ten questions that covered the students' experiences in translation, learning methods, translation aid tools, preferred text materials, course length expectation and willingness to attend the course. Based on data analysis, the student perception and willingness to learn translation was determined. Student perception was crucial for teacher in helping the student to develop an effective learning and develop course design in university setting.

Concerning the effectiveness of translation in learning the target language in general, Machida (2011) discussed the act of translating between mother tongue and second/foreign (SL/FL) language as a potentially effective way to improve learners' SL/FL language. The paper limited its theoretical perspective of the methodology to advanced level learners, and emphasized that the act of translating could create ideal learning opportunities with positive L2 use in SL/FL learning. The researcher argued that the act of translating is a holistic activity, which immediately compels the learners to pay more attention to the SL/FL text, which encourages their awareness of form and meaning in context and improves their reading and writing skills in SL/FL. Scheffler (2012) reassessed a grammar-translation course in language teaching based on learners' perceptions. The article reported a study in which 45 EFL students were asked to evaluate two consciousness raising activities they had performed: Grammar translation task and a communicative language exchange. Results indicated that the learners considered translating sentences from polish into English to be useful and interesting as the communicative oriented activity.

As for the usefulness of translation in improving the four language skills, Lee (2013) did a study with 35 undergraduate students who were enrolled in a translation course at a university in Taiwan to find out whether the use of translation could improve students' reading comprehension. The students were divided into two groups, English majors, and non-English majors. Findings revealed that translation helped students in reading comprehension and it also improved their understanding of the reading passages. Mutlu, et al. (2015) investigated the use of translation by Turkish learners of English to gain the four language skills, reading, listening, writing and speaking and to learn lexical items. The participants of the study were 118 university students. Results showed that the Turkish EFL learners used translation while they were reading an English text and during writing. They also showed that translation used to enhance the four language skills differed according to students' proficiency level.

\subsection{Studies related to the four language skills}

Many studies were conducted on EFL students' attitudes towards teaching and learning the four language skills. Some of these studies were concerned with the oral skills, some were interested in the academic skills, and others emphasized both.

With regard to the oral skills, Živković (2014) conducted a study which aimed to investigate the place of oral presentations for university students. The data were collected using a questionnaire on students' attitudes. Findings indicated that the students were required to take an active role in forming new understandings, and shouldn't be passive receptors. They also indicated that they enjoyed classes including oral activities and they were given the chance to promote creativity and innovation by giving oral presentations. Another study was executed by Kang (2014) who examined 617 students' perceptions and expectations of their pronunciation and their attitudes towards instructors' accent varieties and methods of teaching in the inner circle (The United States and New Zealand), the outer circle (Pakistan and South Africa) and the expanding circle (Japan and South Korea). Findings showed that students in the inner circle and the expanding circle countries were more dissatisfied with the instructors' methods of teaching due to confusion of various models, teachers' mono-model treatment of accent variation, and lack of effort of incorporating the role of English as an international language. In addition, Soomro \& Farooq (2018) conducted a survey study with 184 undergraduate EFL male and female students in Taif University. The aim was to investigate the influence of various factors related to learners, teacher, and learning environment on the students' attitudes towards learning speaking skills. Data analysis showed that level of the students' skills in English was attributed to the variety of teachers', learners', and environment related factors. And these factors affected negatively the attitude of learners towards learning the oral skills.

With respect to the academic skills, Tanni (2014) did a study with 76 EFL students to explore the role of an extensive reading program in developing linguistic competence of university students. The instrument used was a 5-Likert scale developed to achieve the aim of the study. The participants of the study were chosen randomly from the third- and fourth-year EFL students at- Al- Quds Open University in Tulkurm. Results revealed that 
most of the participants agreed that extensive reading had positive impact on developing their linguistic competence. Another study was carried out by Alqouran \& Smadi (2016) who examined the effect of integrating reading and writing in Jordanian undergraduate EFL students' program and explained their attitudes toward the effectiveness of the program in developing their writing skill. 50 undergraduate EFL students from Jordan were divided equally into a controlled group and an experimental one. Results indicated that the program enhanced students' writing performance and the writing sub-skills (i.e., development, organization and language) and affected students' attitudes positively towards these two language skills. Moreover, Khoja, Mohapatra \& Sarma (2018) explored the learning practices that affected students' transition from one level to the next via obtaining students perceptions about writing, challenges they encountered while writing, and the strategies they used to overcome them. Two separate questionnaires were given to 200 students from 7 different high schools across Latakia city and 206 first-year students at the Department of English Literature and Language, Tishreen University. The main findings indicated that students of both levels were mostly concerned with grammar rather than ideas and content, and with the product rather than the process of writing. Moreover, students lacked confidence in their writing ability and mostly depended on ready-made samples and teachers as the main source of information.

As for the role of linguistic competence in improving students' listening and reading comprehension, Oh (2016), for example, undertook comparative studies with 75 Korean students to explore the roles of linguistic knowledge (vocabulary knowledge, grammar knowledge and sentence processing speed) in L2 listening and reading comprehension in an EFL tertiary setting. Results indicated that the three tested components had a significant portion of shared variance in explaining listening comprehension (34\%) and reading comprehension (42\%) without any unique significant contribution of each component.

From the brief literature review above, it is apparent that students' perspectives of each field or course had been investigated separately. That is, a few comprehensive studies were conducted on EFL curricula used in higher education. Therefore, the present research study can be regarded as an attempt to fill a gap in the literature associated with this academic and/or educational field at the university level.

\section{Methodology}

The nature of data collection determines the method to be employed in collecting these data. According to Dornyei and Taguchi (2010), questionnaire is one of the common methods of data collection in L2 research since it is easy to construct, extremely versatile, and capable of gathering a large amount of information quickly. Madziwa (2016) states that there are various methodologies quantitative and qualitative which are available for data collection, of which interviewing is part of it. Madziwa adds that interviewing is a key qualitative data collection method for social research instrument as there is need to attain highly personalized data as well as in cases where there are opportunities for probing to get underlying factors.

\subsection{Instruments}

This current study employed a questionnaire and questionnaire interview. The questionnaire consisted of 36 closed items and 3 open-end questions. The items of the questionnaire were derived from the theoretical background of the study, from the literature review, and from the documents obtained from the English Language Department at the university. These items were divided into four main courses or domains, which are: literature, linguistics, translation, and the four language skills. Integrative and instrumental orientation scales of the original 5-Likert Scale format were used, ranging from 'Strongly Agree' to 'Strongly Disagree'.

In order to insure whether or not the questionnaire is valid, it was handed to several experienced professors teaching in the English Language Department, in the Language Center, and in the Faculty of Educational sciences. Some items were changed according to their suggestions and recommendation. In order to find out the reliability of the questionnaire, the Test- Re-Test way of analysis was employed on 25 of the female students who were not involved in the study. The males were not involved in this process because they were only 44 . As soon as the questionnaire was received from the students, the data were transcribed for the need of statistical analysis. Results indicated that the correlation coefficient was 0.86. Additionally, the Cronbach Alpha coefficient test was done for the items of the questionnaire. Result revealed that the alpha value was found to be 0.84 . With regard to open-end questions, no modifications or changes were suggested by the referees.

\subsection{The Participants}

A total number of 177 students (male 40 and female 137) from the Hashemite University took part in the study. They were third- $(\mathrm{N}=82)$ and fourth- $(\mathrm{N}=95)$ year students chosen randomly from the population of the study.

\subsection{Limitations}

This study was limited to 177 third- and fourth-year undergraduate students majoring English language chosen randomly from the English language department in the Hashemite University in Jordan. The study was 
conducted during the second semester of the academic year 1917/1918.

\subsection{Data Analysis}

In this study, both quantitative and qualitative data were collected. The quantitative data were collected from the closed items in the questionnaire, whereas the qualitative data were collected from the open-end questions. The data obtained from the closed items were analyzed by using descriptive statistics and the t-test. On the other hand, The data obtained from the open-end questions were analyzed by categorizing the raw data according to students' preference of courses and to their views about each course. Then, the similar preferences and views were labeled and the frequency and percentage of their occurrence were calculated.

\section{Results of the Study}

The data obtained from the closed items in the questionnaire were analyzed by using descriptive statistics (i.e., frequencies, means, percentages and standard deviations). The means and standard deviations were used to see whether the students attitudes were positive and for the arrangement of the questionnaire items. The data were also analyzed using the t-test to show whether there were statistically significant differences between the means of students' responses to the questionnaire. On the other hand, the data obtained from the open-end questions were analyzed by categorizing the raw data, labeling them, and then counting frequencies and percentages.

\subsection{Results related to the first research question}

In order to answer the first question "How do the students perceive each course (Domain) implemented in the English language department and the EFL curriculum as a whole?", the means of students' responses to the items of each course were arranged decreasingly in order to show which one the students see it more positively than the other. As shown in table 1.

Table 1: Mean (M) and Standard Deviation (SD) of students' responses to each course and to the four courses together

\begin{tabular}{|l|c|c|}
\hline \multicolumn{1}{|c|}{ Subject/ course } & M & \multicolumn{1}{c|}{ SD } \\
\hline Translation & 4.09 & .629 \\
\hline Four language skills courses & 3.70 & .429 \\
\hline Literature & 3.26 & .628 \\
\hline Linguistics & 3.18 & .869 \\
\hline Mean & 3.6 & .64 \\
\hline
\end{tabular}

Table 1 shows that the students see translation courses $(M=4.09)$ as the most beneficial and the four language skills ones as very beneficial $(M=3.70)$. It also shows that the literature $(M=3.26)$ and linguistics courses $(M=3.18)$ are successively useful. And finally, the table shows that the students perceive the four courses together as beneficial $(\mathrm{M}=3.6)$.

With regard to students' responses to the first open-end question, these responses revealed that $36 \%$ of the respondents revealed their satisfaction with the courses they had in the department, whereas $18 \%$ revealed negative views and the rest reported neutral opinions. As for the second question, results indicated that $35 \%$ of the respondents showed their positive attitude towards the four language skills courses, $6 \%, 6 \%, 5 \%$ agreed successively that the translation, literature and linguistics courses were the most beneficial.

\subsection{Results related to the second research question}

In order to answer the second question "What are the major reasons which cause the students to perceive each course more/ less beneficial?", the means of students' responses to the items of each of the four courses, literature, linguistics, translation, and four language skills were also arranged decreasingly. Samples of the students' views related to the target courses will be presented (see also appendix C and D). Let us now return to students' attitudes (Table 2) and views associated with each course. 


\subsubsection{Literature}

Table 2: The Mean (M) and Standard Deviation (SD) of students' responses to the literature courses

\begin{tabular}{|c|l|c|c|}
\hline Rank & \multicolumn{1}{|c|}{ Literature } & M & SD \\
\hline 1 & Literature courses expose me to fiction, drama, and poetry. & 4.32 & .881 \\
\hline 2 & Literature courses are a good resource of vocabulary, sentence patterns and structure. & 4.25 & .909 \\
\hline 3 & Literature courses are a great way to learn about people's cultures. & 4.10 & .975 \\
\hline 4 & Literature courses are a mean of promoting an active citizen. & 2.97 & 1.234 \\
\hline 5 & Literature courses give me more insight and long life experience. & 2.93 & 1.317 \\
\hline 6 & Literature courses develop my four language skills. & 2.52 & 1.230 \\
\hline 7 & Literature courses provide applications for language practice. & 2.37 & 1.137 \\
\hline 8 & Literature courses are effective in improving my English language competence. & 2.26 & 1.173 \\
\hline & Total mean & 3.26 & .628 \\
\hline
\end{tabular}

Table 2 shows that the major reasons the students perceive the literature courses as the most beneficial are: they expose them to fiction, drama, and poetry $(\mathrm{M}=4.32)$, they are a good resource of vocabulary and structure $(M=4.25)$ and they are a great way to learn about other peoples' cultures $(M=4.10)$. It also shows that the reasons for perceiving these courses as the least beneficial are associated with the lack of developing students' four language skills $(\mathrm{M}=2.52)$, the lack of providing applications for language practice $(\mathrm{M}=2.37)$ and the lack of improving their English language competence $(\mathrm{M}=2.26)$. With regard to students' views, some of them agree with the attitudes towards some of the items related literature, arguing that literature courses are a source of new vocabulary which can be used in their daily life. As two of the students state:

Literature enrich my words

Literature provides me with new vocabulary

Other students declared that the literature courses enriched their ideas, were interesting, and influenced their lives in general and their way of thinking in particular. As they argue:

These courses introduce new ideas to me as a student

Literature has an influence on my real life

Literature is interesting

Literature has changed my way of thinking

As for the reasons behind not preferring the literatures courses, some new ideas mostly related to boredom, future career, the relationship between literature and real-life and students' communication inside the classroom came up. As some of the students state:

Literature is not useful for my future career as a teacher

We don't communicate inside the class

The whole class is for the professor, we never have the chance to participate

Literature is not accurate

Literature didn't add anything to my skills

\subsubsection{Linguistics}

Table 3: The Mean (M) and Standard Deviation (SD) of students' responses to the linguistics courses

\begin{tabular}{|c|l|c|c|}
\hline Rank & \multicolumn{1}{|c|}{ Linguistics } & M & SD \\
\hline 1 & $\begin{array}{l}\text { Linguistics courses provide me with basic descriptive levels of language and its } \\
\text { relationship with other social disciplines. }\end{array}$ & 3.94 & 1.137 \\
\hline 2 & Linguistics courses help to develop my reading comprehension & 3.69 & 1.318 \\
\hline 3 & Linguistics courses help to develop my pronunciation and listening comprehension. & 3.64 & 1.311 \\
\hline 4 & Linguistics courses are important for the grammatical construction. & 2.94 & 1.443 \\
\hline 5 & Linguistics courses are important for the language understanding as a whole. & 2.85 & 1.452 \\
\hline 6 & Linguistics courses help me in my life beyond the classroom. & 2.82 & 1.370 \\
\hline 7 & Linguistics courses are important to acquire language proficiency. & 2.78 & 1.455 \\
\hline 8 & $\begin{array}{l}\text { Linguistics courses acquaint me with the nature of human language, its characteristics, } \\
\text { functions and components. }\end{array}$ & 2.75 & 1.334 \\
\hline & Total mean & 3.18 & .839 \\
\hline
\end{tabular}

Table 3 shows that the students perceive the linguistics courses as the most beneficial for the following reasons: they provide them with basic descriptive levels of language and its relationship with other social disciplines $(M=3.94)$ and they help to develop students' reading comprehension $(M=3.69)$. Nevertheless, the students reveal that the reasons for their perception of these courses as the least beneficial are: they are not important to acquire language proficiency $(\mathrm{M}=2.78)$ and they do not acquaint them with the nature of human language, its characteristics, functions and components $(M=2.75)$. Regarding the reasons for viewing linguistics courses as the most beneficial, the majority of the students in the questionnaire interview attributed their positive 
view to phonology and attitude towards life. As they state:

Linguistics courses acquired me with the English accent

Linguistics courses introduce English language sounds

These courses have improved my points of view of language

Linguistics courses help me in pronunciation

Some of the students' views do not agree with their attitudes in the questionnaire. They thought that the linguistics courses did not help in teaching language and in developing speaking and listening skills. They also thought that these courses were not related to their life and neither important nor useful. As they argue:

Why are we supposed to use linguistics?

Linguistics can't be used outside the classroom

A branch of linguistics which is sociolinguistics is not logic related courses, so it is (should) not to be studied

Linguistics can be taught through other courses

There are much information to memorize but (we) don't know when and how to use them

Linguistics courses have much information without application

\subsubsection{Translation}

Table 4: The Mean (M) and Standard Deviation (SD) of students' responses to the translation courses

\begin{tabular}{|c|l|c|c|}
\hline Rank & \multicolumn{1}{|c|}{ Translation } & M & SD \\
\hline 1 & $\begin{array}{l}\text { Translation courses point out cultural and linguistic differences between Arabic and } \\
\text { English. }\end{array}$ & 4.27 & .968 \\
\hline 2 & Translation courses train me to translate into and out of English. & 4.24 & .898 \\
\hline 3 & $\begin{array}{l}\text { Translation courses draw my attention to the various difficulties facing the translator in } \\
\text { general. }\end{array}$ & 4.20 & .995 \\
\hline 4 & $\begin{array}{l}\text { Translation courses make an agreement between my needs and the aim of the courses I } \\
\text { have. }\end{array}$ & 4.07 & .914 \\
\hline 5 & Translation courses help improving my reading and writing skills. & 4.05 & .999 \\
\hline 6 & Translation courses encourage my awareness of form and context. & 4.02 & 1.008 \\
\hline 7 & Translation courses enhance my cultural background knowledge. & 3.99 & .929 \\
\hline 8 & Translation courses enable me to master the written components of a foreign language. & 3.87 & .971 \\
\hline & Total mean & 4.09 & .629 \\
\hline
\end{tabular}

Table 4 shows that the reasons behind which the students see translation courses as the most useful are related to the cultural and linguistic differences between Arabic and English $(\mathrm{M}=4.27)$, translation into and out of English $(M=4.24)$, the various difficulties facing the translator in general $(M=4.2)$. It also shows the reason behind which the students see these courses as the least beneficial. It is associated with the degree of help these courses offered them to master the written components of a foreign language $(M=3.87)$. As for the students' views, some of them agreed with their attitudes in the questionnaire. For example, the students argued that the translation courses helped in improving their reading and writing skills, trained them to master English language aspects and improved their knowledge of the English culture. However, some students suggested new ideas relevant to acquainting them with new vocabulary words and to helping them in their daily life. As they state:

I use the four language skills during the translation courses

Help me to learn new vocabulary

Help me in improving my reading and writing skills

Train and help me in understanding language aspects like grammar 


\subsubsection{The four language skills}

Table 5: The Mean (M) and Standard Deviation (SD) of students' responses to the four language skills courses

\begin{tabular}{|c|l|c|c|}
\hline Rank & \multicolumn{1}{|c|}{ The four language skills } & M & SD \\
\hline 1 & Oral skills courses increase my listening and speaking capabilities. & 4.22 & 1.007 \\
\hline 2 & $\begin{array}{l}\text { Reading and writing courses enhance my writing sub-skills such as (development, } \\
\text { organization and language) }\end{array}$ & 4.22 & 1.012 \\
\hline 3 & Writing courses enhance my writing performance. & 4.20 & .873 \\
\hline 4 & The research project course beneficial for me in my future academic career. & 4.15 & .926 \\
\hline 5 & Writing before, after and while reading makes me familiar with the text characteristics. & 4.15 & .892 \\
\hline 6 & Oral skills courses help me to communicate meaningfully in future career. & 4.12 & .967 \\
\hline 7 & Writing courses are important in pursing my discipline. & 4.10 & 1.021 \\
\hline 8 & Oral skills courses give me the chance to speak about interesting literal texts. & 4.08 & .968 \\
\hline 9 & $\begin{array}{l}\text { Extensive reading courses may have a significant positive effect on my witing } \\
\text { performance. }\end{array}$ & 4.05 & .934 \\
\hline 10 & $\begin{array}{l}\text { Oral skills courses enable me to listen comprehensively to all the lectures given at the } \\
\text { English department. }\end{array}$ & 4.04 & .919 \\
\hline 11 & Oral skills courses give me the chance to promote creativity. & 4.03 & 1.002 \\
\hline 12 & Reading courses help me to achieve the learning outcomes in the EFL curriculum. & 4.03 & .994 \\
\hline 13 & Four Language Skills & 4.11 & .526 \\
\hline & Total mean & 4.70 & .429 \\
\hline
\end{tabular}

The table above shows that all of the courses allotted to the four language skills were beneficial in general. However, Table 5 shows that the reasons behind which the students perceive these courses as the most useful are successively associated with listening and speaking capabilities $(M=4.22)$, to reading and writing and their role in enhancing their writing sub-skills $(M=4.22)$, and to the writing courses which enhance their writing performance $(M=4.20)$. The table also reveals that the students see these courses as the least beneficial because they did not give them the chance to promote creativity $(M=4.03)$ and the reading courses did not help them to achieve the learning outcomes in the EFL curriculum $(\mathrm{M}=4.03)$. Concerning students' views, some of them agreed with some of their attitudes in the questionnaire. The students thought that the oral skills courses improved their listening and speaking abilities and gave them the chance to communicate freely in the classroom. They also thought that the reading courses helped them achieve their goals and writing skills in general should be acquired well.

Many students declared that the four language skills courses were interesting and useful. The reasons are associated with personality, career, role, basis of language, knowledge, and to vocabulary enrichment. Here are some new positive ideas stated by the students:

The four language skills improved my abilities and my personality

Oral skills are needed for my future career

The four language skills are the bases of learning English

Reading and writing courses improved my knowledge of the language

Reading and writing courses increased my vocabulary

However, some students do not view the four language skills courses as useful courses for these reasons:

In reading 1 course, students from different majors are mixed together, so this course is too easy for an English major student and seen to be useless

The oral skills don't provide us with information which could be used

The four language skills courses didn’t improve my skills as expected

\subsection{Results related to the third research question}

In order to answer the third question "Are there any statistical significant differences $(\boldsymbol{\sigma}=\mathbf{. 0 5})$ between the means of students' responses due to gender?". the means, standard deviations and the 2-tailed significance were used. As seen in table 6: 
Table 6: The Means (M), Standard Deviations (SD) and the t-value with 2-tailed sig. of students' responses to each course and to the four courses together due to gender

\begin{tabular}{|c|c|c|c|c|c|c|c|}
\hline Subject & Gender & $\mathbf{N}$ & Mean & Std. Deviation & $\mathbf{t}$ & df & $\begin{array}{c}\text { Sig. } \\
\text { (2-tailed) }\end{array}$ \\
\hline \multirow[t]{2}{*}{ Literature } & Male & 40 & 2.83 & .663 & \multirow[t]{2}{*}{-5.193} & \multirow[t]{2}{*}{175} & \multirow[t]{2}{*}{.000} \\
\hline & Female & 137 & 3.38 & .563 & & & \\
\hline \multirow[t]{2}{*}{ Linguistics } & Male & 40 & 2.84 & .908 & \multirow[t]{2}{*}{-2.911} & \multirow[t]{2}{*}{175} & \multirow[t]{2}{*}{.004} \\
\hline & Female & 137 & 3.27 & .795 & & & \\
\hline \multirow[t]{2}{*}{ Translation } & Male & 40 & 3.86 & .859 & \multirow[t]{2}{*}{-2.644} & \multirow[t]{2}{*}{175} & \multirow[t]{2}{*}{.009} \\
\hline & Female & 137 & 4.15 & .530 & & & \\
\hline \multirow[t]{2}{*}{ Four Language Skills } & Male & 40 & 3.91 & .717 & \multirow[t]{2}{*}{-2.913} & \multirow[t]{2}{*}{175} & \multirow[t]{2}{*}{.004} \\
\hline & Female & 137 & 4.18 & .440 & & & \\
\hline \multirow[t]{2}{*}{ All items } & Male & 40 & 3.42 & .593 & \multirow[t]{2}{*}{-5.037} & \multirow[t]{2}{*}{175} & \multirow[t]{2}{*}{.000} \\
\hline & Female & 137 & 3.78 & .327 & & & \\
\hline
\end{tabular}

Table 6 shows statistical significant differences at $(\alpha=0.05)$ between the means of students' responses to each of the four courses in favor of females. The table also shows statistical significant differences $(\alpha=0.05)$ between the means of students' responses to the four courses in favor of females.

\subsection{Results related to the fourth question}

In order to answer the fourth question "Are there any statistical significant differences $(\boldsymbol{\sigma}=\mathbf{. 0 5})$ between the means of students' responses due to study year $\left(3^{\text {rd }}\right.$, and $4^{\text {th }}$. Years $)$ ?", the means, standard deviation and the 2tailed significance were also used. As presented in table 7:

Table 7: The Mean (M), Standard Deviation (SD) and the t-value with 2-tailed sig. of students' responses to each course and to the four courses together due to study year

\begin{tabular}{|c|c|c|c|c|c|c|c|}
\hline & Study year & $\mathrm{N}$ & Mean & Std. Deviation & $\mathrm{t}$ & $\mathrm{df}$ & Sig. (2-tailed) \\
\hline \multirow[t]{2}{*}{ Literature } & third year & 82 & 3.34 & .670 & \multirow[t]{2}{*}{1.728} & \multirow[t]{2}{*}{175} & \multirow[t]{2}{*}{.086} \\
\hline & fourth year & 95 & 3.18 & .583 & & & \\
\hline \multirow[t]{2}{*}{ Linguistics } & third year & 82 & 3.30 & .875 & \multirow[t]{2}{*}{1.789} & \multirow[t]{2}{*}{175} & \multirow[t]{2}{*}{.075} \\
\hline & fourth year & 95 & 3.07 & .797 & & & \\
\hline \multirow[t]{2}{*}{ Translation } & third year & 82 & 4.07 & .590 & \multirow[t]{2}{*}{-.388} & \multirow[t]{2}{*}{175} & \multirow[t]{2}{*}{.698} \\
\hline & fourth year & 95 & 4.10 & .663 & & & \\
\hline \multirow[t]{2}{*}{ Four Language Skills } & third year & 82 & 4.07 & .575 & \multirow[t]{2}{*}{-1.053} & \multirow[t]{2}{*}{175} & \multirow[t]{2}{*}{.294} \\
\hline & fourth year & 95 & 4.15 & .478 & & & \\
\hline \multirow[t]{2}{*}{ All items } & third year & 82 & 3.72 & .469 & \multirow[t]{2}{*}{.681} & \multirow[t]{2}{*}{175} & \multirow[t]{2}{*}{.497} \\
\hline & fourth year & 95 & 3.68 & .392 & & & \\
\hline
\end{tabular}

Table 7 shows no statistical significant differences at $(\alpha=0.05)$ between the means of students' responses to each of the four courses due to study year. The table also shows no statistical significant differences $(\alpha=0.05)$ between the means of students' responses to the four courses together.

\subsection{Discussion of the Results}

This current study aimed to explore a sample of EFL undergraduate students' perspectives of the curriculum employed in the English Language Department at the Hashemite University. In order to achieve this aim, the study attempted to answer four research questions through the results presented above. However, this section will discuss the results of each question.

Regarding the first research question about the students' perception of each course implemented in the English Language Department and the EFL curriculum as a whole, results showed that the students perceived the translation and four language skills courses as the most beneficial and the linguistics courses as the least. As for the questionnaire interview, the students also thought that the four language skills courses the most beneficial and a few perceived the translation, literature and linguistic courses as beneficial. We think that the reason behind such a positive perception of the translation and four language skills courses lays in the fact that the nature of their requirements encourages interaction between the teacher and students and among the students themselves. We also think the reason behind their negative perception of the linguistic courses, for example, is related to the vagueness of some of the rules and skills and of the difficulty of explaining their applications in genuine situations. However, the majority of the studies done on the four language skills indicated students' positive attitudes towards them (See, for example, Zivkovic, 2014; Tanni, 2014; \& Alqouran \& Smadi, 2016). Many researchers necessitated the importance of integrating the oral skills, the academic skills and the four language skills together because of their mutual impact on each other (Alonso, 2013; Prew, 2014; \& Zhao \& 
Hiravela, 2015). Concerning the translation courses which were regarded to be beneficial, several researchers highlighted the importance of translation in general. For example, Calis \& Dikilitas (2012) argue that translation is normally favored by learners as it promotes different aspects of learning. Artar (2017) also argues that translation can be used to gain proficiency in a language so as to be a more competent user of that language.

Concerning the second research question which investigated the major reasons of perceiving each course more/less beneficial, quantitative and qualitative results indicated that the students perceived the literatures courses as more beneficial because they exposed them to fiction, drama and poetry, they were a source of vocabulary and structure and they were a way of learning cultures. These results agree with the aim and description of this course and with what (Tompkins, 1993 \& Zapata, 2005) argued. They also agree with what was found by (Coskun \& Ogeyik, 2007; Cirakli \& Kilickaya, 2011; Darwish \& Shuqair, 2015; \& Tevdovsk, 2016) in their research studies. Results also showed that the students perceived these courses as less beneficial since they did not fully develop the students' four language skills. This does not agree with what was insisted by (Abdeen, 2006) that these courses often improve students' English language competence.

As for the linguistic courses, results showed three main reasons for viewing them as beneficial. That is, they provided students with basic descriptive levels of language, they helped them in developing their oral skills, and its relationship with other social disciplines. This agrees with the aims of the curriculum and with what was suggested by (Hassoon, 2014) that linguistics plays an important role in the grammatical construction of language. This also coheres with what was found by (Belgrave \& Jules, 2015) that greater focus on studentcentered principles of best practice would enhance the worth and usefulness within broader world context and with what was argued by (Loreto, 2007) that the linguistics courses help to develop students' reading comprehension. Moreover, the results showed that the students viewed these courses as not beneficial because they were not important in acquiring language proficiency and they could not be used outside the classroom. This does not agree with what was stated by (Johansson, 2001) that linguistics helps learners to understand the use of its principles outside and with what was suggested by (Hassoon, 2014) that linguistics plays an important role in comprehending the sides which are required to acquire language proficiency.

With respect to translation courses, results revealed that the reasons behind perceiving them as beneficial are: they pointed out cultural and linguistic differences between Arabic and English, they trained students to translate into and out of English, they drew their attention to the various difficulties facing the translator in general, they helped in improving their reading and writing skills, and they enriched their knowledge of English language culture. These results agree with those found by (Machida, 2011; Schefler, 2012, Lee, 2013; \& Mutlu, et al. 2015). Further, the results indicated that the students perceived these courses as less beneficial because they did not enhance fully their cultural background knowledge and their mastery of the written components of the target language. These results do not cohere with what was argued by (Machida, 2011) that the act of translating is a holistic activity which encourages the learners to be aware of form and meaning in context and improves their academic skills.

In terms of the four language skills courses, results showed that the reasons for viewing them as very beneficial are related to the impact of these skills on improving their knowledge of the language, on enriching their vocabulary and on developing their personalities. They are also associated with their benefit in the future career and with the text characteristics. These results cohere with the aims of these courses stated by the English language department at the university. They also cohere with what was argued by (Alonso, 2013) that proficiency in the oral skills is seen as a desirable goal for EFL university learners, with what was stated by (Prew, 2014) that the oral skills aid learners of English to communicate for a better future career and social stability, and with what (Alqouran \& Smadi, 2016) and other researchers emphasized that it is important to integrate reading and writing as the two skills involve similar cognitive processes. The results also agree with what was found by (Zivkovic, 2014) that students enjoyed classes including oral activities as they were given the chance to promote creativity and with what was obtained by (Tanni, 2014) that most of the participants agreed that extensive reading had positive impact on developing their linguistic competence in the English language. Moreover, the results indicated that the students perceived these courses as less or not beneficial as the oral skills courses did not fully give the students the chance to promote creativity, to achieve the learning outcomes of the curriculum, to enrich them with information, and to use the four language simultaneously. We think that the lack of integration of the four language skills, listening, speaking, reading and writing and the division of these courses into separate islands caused the students to view these courses as less or not beneficial in achieving the learning outcomes of the curriculum and in enriching them with information.

As for the third research question, results showed statistically significant differences $(\alpha=0.05)$ between the means of students' responses to each of the four courses and to the four together in favor of females. It was expected that the mean of females' responses would be higher than that of the males'. This could be attributed to the assumption that females have a more positive attitude towards learning a foreign language and do better than males in this regard. This is in consistent with what (Ellis, 1994) argued that women usually have a more positive attitude towards learning a second language, which has a great impact on their way of learning. 
Regarding the fourth research question, results revealed no statistically significant differences $(\alpha=0.05)$ between the means of students' responses to each of the four courses and to all together according to study year. It was expected that the fourth-year students would have a more positive attitude towards the curriculum as they went deeper into their specialization and attended various courses. This might enable them to recognize the importance of each course and the usefulness of the curriculum as a whole.

\section{Recommendations}

Several recommendations could be suggested with regard to the field of this research study. They are:

1. EFL curriculum designers at the university level ought to be aware better of the importance of students' perspectives in developing and/or improving the relevant courses allotted to this curriculum.

2. Teachers of EFL courses should make more effort and use better methods of teaching these courses, particularly those related the linguistics and literature ones.

3. Other research studies should be conducted on EFL teachers' perspective of these courses or sub-courses in the curriculum.

4. Other research studies should be done using qualitative instruments such as interviews and observations in order for the latter to supporter the former.

\section{Conclusion}

Conducting research studies on English as an international language and at the university level is of paramount importance nowadays. The reason lies in the fact that the target subjects will be an important axis around which everything revolves in the teaching-learning context. Therefore, their views should be taken into consideration seriously with regard to the courses they have, to the teachers of these courses and to the methods of teaching they use. Insisting on the subjects' or students' views has come as a result of excluding them from the development of any curriculum or any course, particularly in developing countries. As a result, a needs analysis ought to be made from now and then for the purpose of improving the input which normally affects greatly the output.

Therefore, this current study may be regarded as an attempt to shed light on the strong and weak points of an EFL curriculum at the university level. The purpose is to support the strong points and to overcome the weak ones. In other words, when the student says that this or that course is effective or ineffective, his or her attitude or view ought to be taken into account in any department interested in English as a foreign or second language.

\section{Acknowledgement}

We are grateful to the participants of this study (the EFL students) and to their teachers for their time and effort. We would also like to thank Prof. Ali Farhan for his invaluable comments and suggestions.

\section{References}

Abdulhafidh, E. (2015). The Role of English in Present Day Higher Education. Conference Paper: Conference $5^{\text {th }}$. International Visible Conference on Educational Science, At Erbil, Iraq, 7. Available online: http://en.wikipedia.org/wiki/Education.pdf

Ahmed, S. (2015). Attitudes towards English Language Learning among EFL Learners at UMSKA. Journal of Education and Practice, 6, 6-17. Available online: http://files.eric.ed.gov

Al-Darwish, S. \& Shuqair, K.H. (2015). The use of Literature in an EFL Classroom. British Journal of Education, 3, 71-82. Available online: http://www.eajournals.org.

Al Fallaj, F. (2013). The Use of Linguistics in Teaching Pronunciation to Saudi Students" Journal of Humanities, $14,134-143$.

Alfauzan, A., \& Hussain, A. (2017). Attitude towards and Perception of Literature in EFL Setting: A case Study on WI Mates Undergraduate Students". English Language Teaching, 10, 1-17. Available online: http://files.eric.ed.gov.pdf

Al Ghazo, M. and Al Ghazo, K. (2007). The Effect of Linguistic Complexity on the Reading Comprehension of Jordanian Students Learning English as A Foreign. Education, Alazhar University, 3, 511- 526. Google.com/search?riz

Al-khatib, K. (2013). Can Universal Linguistic Fundamentals Contribute to the Interpretation of EFL Learning. European Scientific Journal, 9(35), 28-43. eujournal org/index php/esj/article/viewFile/2182/2067

Al-Mahrooqi, R., \& Al-Wahaibi, T. (2012). EFL Students' Attitudes towards Studying Literature at Higher Education Institution in Oman. European Journal of Social Sciences, 32(1), 77-93. Available online: http://researchgate.net.pdf

Alonso, S. (2013). The Importance of Teaching Listening and Speaking Skills. M. A., Thesis. Dpto. Didáctica de la Lengua y la Literatura Facultad de Educación, Spain. Available online: http://www.ucm.es

Alqouran, A., \& Smadi, O. (2016). The Effect of Reading-Writing Integration on Jordanian Undergraduate 
Students' Writing Performance" Arab World English Journal (AWEJ), 7(2), 177-189. Available online: http://semanticscholar.org.pdf.

Artar, B (2017). The Role of Translation in Foreign -Language Teaching. Doctoral Thesis, Universitat Rovira I Virgili, 1-229. Available online: http://www.tesisenred.net.pdf

Babaee, R. and Yahya, W. (2014). Significance of Literature in Foreign Language Teaching" International Education Studies, 7, 80-85. Available online: http://dx.doi.org/10.5539/ies.v7n4

Belgrave, K.L.,\& Jules, J.E. (2015). Students' Attitudes towards Research: Applying best Practice Principles through a Student Centred Approach. Paper presented at the Regional Conference on Institutionalizing best Practice in Higher Education, UWI. Available online: http://hdl.handle.net/2139/40093

Bygate, M. Swain, M., \& Skehan, P. (2013). Researching Pedagogic Tasks: Second Language Learning and Teaching. Testing third edition. Routhedge, 2 park square, Milton. Park, Abingdon, New York, USA. books.google.jo

Calis, E. \& Dikilitas, K. (2012). The Use of Translation in EFL Classes as L2 Learning Practice. Procedia-Social and Behavioral Sciences, 5079-5084. Available online: http://www.sciencedirect.com.pdf

Cirakli, M., \& Kilickaya, F. (2011). Literature Courses in EFL Curriculum: Pre-Service Language Teachers' Perceptions. Journal of Education and Instruction (PEGEGOG), 1, 11-15. Available online: http://www.pegem.net.pdf

Coskun, M., \& Ogeyik, R. (2007). Attitudes of the Students in English Language Teaching Programs towards Literature Teaching" Eurasia Journal of Educational Research, 27, 151-162. Available online: http://scholar.google.com

Darwish, S., \& Shuqair, K. (2015). The Use of Literature in an EFL Classroom” British Journal of Education, 3 , 71-82. http://www.eajournals.org.pdf

Dornyei, Z., \& Taguchi, T. (2010). Questionnaires in Second Language Research: Construction, Administration, and processing. $2^{\text {nd }}$ Edition.UK: Routlege.

Ellis, R. (1994). The Study of Second Language Acquisition. Press, First Edition,Oxford, Oxford University Press..

Hassoon, N. (2014). Cognitive Linguistics and EFL. Babylon Center for Human Studies Journal, 4, 1-13. Google.com/search?9

Kang, O. (2014). Learners' perceptions toward Pronunciation Instruction in Three Circes of World Englishes. TESOL Journal (0.0), 1-22. Available online: http://www.researchgate.net

Karavas, E. (2014). Applied Linguistics to Foreign Language Teaching and Learning. Foreign Language Curriculum and Syllabus Design. Edition: 1.0. Available online: http://opencourses.uoa.gr/courses/ENL5.pdf

Karoly, A. (2011). Exploring Learners' Needs and Expectations: Translating EU Texts in an English Bachelor's Programme at a Hungarian College. WoPaLP, 6, 58-85. longped.elte.hu

Khoja, B., Mohapatra, D., \& Sarma, M. (2018). Writing in EFL: Exploring Students' Perspectives in Syrian High School and University Contexts. International Journal of Foreign Language Teaching \& Research, 6(22), 11-31. Available online: www.researchgate.net/publication/32484999

Koban, D., \& Koc, E. (2016). Studnets' Perception of Blog Use in an Undergraduate Linguistic Course. Journal of Language and Linguistic Studies, 12(1), 9-19. Available online: www.jlls.org.pdf

Lee, T. (2013). Incorporating Translation into the Language Classroom and its Potential Impacts upon L2 Learners. In: Translation in Language Teaching and Assessment, Tsagari, D and Floros, G. (Ed): Cambridge Scholars Publishing, 3-18. Available online: http:/www.researchgate.net

Loreto, M. (2007). Applied Linguistics/Learning to Read in ESL”. Literatura y Lingüística, 18, $233-251$. Available online: http://scieio.conicyt.ci

Machida, S. (2011). Translation in Teaching a Foreign (Second) Language: A Methodological Perspective. Journal of Language Teaching and Research, 2, 740-746. Available online: http://www.academia.edu

Madziwa, M. N. (2016). Interviewing as a Data Collection Method. LinkedIn. Available online: http://www.linkedin.com

Moreno, P. (2000). The Implications of Curriculum Design for a Graduate of the English Language Program" Universidad Veracruzana, 20, 130-142. Google.com/search

Mutlu, G., Bayram, D., \& Demirbuken, B. (2015). Translation as Learning Strategy of Turkish EFL Learners. International Journal on New Trends in Education and Their Implications, 6, 236- 245. Available online: http://ijonte.org.pdf

Oh, E. (2016). Comparative Studies on the Roles of Linguistic Knowledge and Sentence Processing Speed in L2 Listening and Reading Comprehension in an EFL Tertiary Setting" Reading Psychology, 37(2), 257-285. Eric.ed.gov.

Pan, L. (2014). Multimodality of Contextualization in Advertisement Translation: a Case study of Billboards in Hong Kong. The Journal of Specialized Translation, 3, 1-6. Available on line: http://www.jostrans.org 
Prew, P. L. (2014). Oral and Aural English as a Foreign Language Needs at an International School. Second Language Studies, 2, 26-75. Available online: http://hawii.ed

Rezvani, R., \& Vakilinejad, M. (2015). Examining Curriculum Efficiency from Learners' Perspective: a Case Study of Translation Criticism Course of Iranian Universities", International Journal of Applied Linguistics and English Literature, 4, 151-158. Available online: researchgate.net

Sadiku, L.M. (2015).The Importance of Four Skills Reading, Speaking, Writing, Listening in a Lesson Hour. European Journal of Language and Literature Studies, 1(1), 29-31. Available online: http://journals.euser.org.pdf

Scheffler, P. (2012). Learners' Perceptions of Grammar -Translation as Consciousness Raising. Language Awareness, 22, 255-269. Available online: http://dol.org.pdf

Sidek, H. (2010). An Analysis of the EFL Secondary Reading Curriculum in Malazya: Approaches to Reading and Preparation for Higher Education, Ph.D. Thesis, 1-159, University of Pittsburgh, Malasya.

Siregar, R. (2018). Exploring the Undergraduate Students Perception on Translation-A Preliminary Step to teach Translation in EFL Classes. English Language Teaching, 11(9), 90-101. Available online: http://researchgate.net.

Soomro, A.F., Farooq, U. (2018). EFL Learners' Attitude towards Developing Speaking Skills at the University of Taif, Saudi Arabia. International Journal of English Linguistics, 8(3), 318-327). Available online: http://www.researchgate.net.pdf

Syarif, H. (2016). Linguistics and the English Language Instruction. Lingua Didaktika, 1(1), 50-59. Available online: http://ejournal.tmp.ac.id/index.php/lingudidaktika/index.pdf

Tanni, Z. (2014). The Effect of Extensive Reading on Developing Students' Linguistics Competence in L2 as Perceived By Third and Fourth Year English Majors at Al-quds Open University" Arabic Studies in Education and Psychology, 2, 275- 292. Available online: http://www.researchgate.net

Taylor, R. (2009). The Paradox of University EFL: a Liberal Arts Subject without Liberal Arts Content" A Journal of English Studies, 4, 160-167. Available online: http://tci-thaijo.org

Tevdovska, E.S. (2016). Literature in ELT Setting: Students' Attitudes and Preferences towards Literary Texts. Procedia-Social and Behavioral Sciences, 232, 161-169. Available online: http://www.sciencedirect.com.pd

Tompkins, G. E. (1993). Teaching Reading with Literature: Case Studies to Action Plans First Edition. Macmillan Publishing Company, USA. Available online: http://books.google.com

Webb, N. (2018). 5 Benefits of Linguistic Learning. Techspective...a Unique Perspective on Technology. Available online: http://techspective.net.pdf

White, R. (2018). What is the Significance of Literature in our Life. Quora.com: Life and Living. View 4 upvoters. Available online: http:/www.quora.com.pdf

Zapata, G. (2005). Literature in L2 Spanish Classes: An Examination of Focus-on Cultural Understanding" Language Awareness, 14, 261-273. Available online: http://www.researchgate.net

Zhao, R., \& Hirvela, A. (2015). Undergraduate ESL Engagement in Academic Reading and Writing in Learning to Write a Synthesis Paper. Reading in a Foreign Language, 27, 219- 241. Available online: http://nfirc.hawii.edu

Živković, S. (2014). The Importance of Oral Presentations for University Students. Mediterranean Journal of Social Sciences, 5(19), 468- 475. Available online: http://semantic scholar.org.pdf

\section{Appendices \\ Appendix B \\ The Questionnaire}

Dear students,

I am conducting this study to investigate the EFL undergraduate students' perspectives of the curriculum (I, e. courses or subjects) employed by the English language department in the Hashemite University. To achieve the aim of the study, a questionnaire has been developed from the University documents, from the theoretical background, and the literature review.

At the moment, I am in need of your viewpoints about each of the subjects you have had so far. Please put a tick next to each item which represents your agreement or disagreement. 


\begin{tabular}{|c|c|c|}
\hline $\begin{array}{cc}\text { Gender: } & \text { Male }( \\
\text { Study year: } & 3^{\text {rd }} \text { year }( \\
\text { Thank you for your cooperation }\end{array}$ & ) & $\begin{array}{l}\text { Female ( } \\
4^{\text {th }} \text { year }(\end{array}$ \\
\hline
\end{tabular}

\begin{tabular}{|c|c|c|c|c|c|}
\hline Literature & $\begin{array}{l}\text { Strongly } \\
\text { agree }\end{array}$ & Agree & Neutral & Disagree & $\begin{array}{l}\text { Strongly } \\
\text { disagree }\end{array}$ \\
\hline \multicolumn{6}{|l|}{$\begin{array}{l}\text { 1. Literature courses expose me to fiction, drama, } \\
\text { and poetry. }\end{array}$} \\
\hline \multicolumn{6}{|l|}{$\begin{array}{l}\text { 2. Literature courses are a good resource of } \\
\text { vocabulary, sentence patterns and structure. }\end{array}$} \\
\hline \multicolumn{6}{|l|}{$\begin{array}{l}\text { 3. Literature courses are a great way to learn about } \\
\text { people's cultures. }\end{array}$} \\
\hline \multicolumn{6}{|l|}{$\begin{array}{l}\text { 4. Literature courses are a mean of promoting an } \\
\text { active citizen. }\end{array}$} \\
\hline \multicolumn{6}{|l|}{$\begin{array}{l}\text { 5. Literature courses develop my four language } \\
\text { skills. }\end{array}$} \\
\hline \multicolumn{6}{|l|}{$\begin{array}{l}\text { 6. Literature courses are effective in improving my } \\
\text { English language competence. }\end{array}$} \\
\hline \multicolumn{6}{|l|}{$\begin{array}{l}\text { 7. Literature courses provide applications for } \\
\text { language practice. }\end{array}$} \\
\hline \multicolumn{6}{|l|}{$\begin{array}{l}\text { 8. Literature courses give me more insight and long } \\
\text { life experience. }\end{array}$} \\
\hline Linguistics & $\begin{array}{c}\text { Strongly } \\
\text { agree }\end{array}$ & Agree & Neutral & Disagree & $\begin{array}{l}\text { Strongly } \\
\text { disagree }\end{array}$ \\
\hline \multicolumn{6}{|l|}{$\begin{array}{l}\text { 1. Linguistics courses provide me with basic } \\
\text { descriptive levels of language and its relationship } \\
\text { with other social disciplines. }\end{array}$} \\
\hline \multicolumn{6}{|l|}{$\begin{array}{l}\text { 2. Linguistics courses acquaint me with the nature } \\
\text { of human language, its characteristics, functions } \\
\text { and components. }\end{array}$} \\
\hline \multicolumn{6}{|l|}{$\begin{array}{l}\text { 3. Linguistics courses are important for the } \\
\text { language understanding as a whole. }\end{array}$} \\
\hline \multicolumn{6}{|l|}{$\begin{array}{l}\text { 4. Linguistics courses are important for the } \\
\text { grammatical construction. }\end{array}$} \\
\hline \multicolumn{6}{|l|}{$\begin{array}{l}\text { 5. Linguistics courses are important to acquire } \\
\text { language proficiency. }\end{array}$} \\
\hline \multicolumn{6}{|l|}{$\begin{array}{l}\text { 6. Linguistics courses help to develop my } \\
\text { pronunciation and listening comprehension. }\end{array}$} \\
\hline \multicolumn{6}{|l|}{$\begin{array}{l}\text { 7. Linguistics courses help me in my life beyond } \\
\text { the classroom. }\end{array}$} \\
\hline \multicolumn{6}{|l|}{$\begin{array}{l}\text { 8. Linguistics courses help to develop my reading } \\
\text { comprehension. }\end{array}$} \\
\hline Translation & $\begin{array}{r}\text { Strongly } \\
\text { Agree } \\
\end{array}$ & Agree & Neutral & Disagree & $\begin{array}{l}\text { Strongly } \\
\text { disagree }\end{array}$ \\
\hline \multicolumn{6}{|l|}{$\begin{array}{l}\text { 1. Translation courses point out cultural and } \\
\text { linguistic differences between Arabic and English. }\end{array}$} \\
\hline \multicolumn{6}{|l|}{$\begin{array}{l}\text { 2. Translation courses train me to translate into and } \\
\text { out of English. }\end{array}$} \\
\hline \multicolumn{6}{|l|}{$\begin{array}{l}\text { 3. Translation courses draw my attention to the } \\
\text { various difficulties facing the translator in general. }\end{array}$} \\
\hline \multicolumn{6}{|l|}{$\begin{array}{l}\text { 4. Translation courses enhance my cultural } \\
\text { background knowledge. }\end{array}$} \\
\hline \multicolumn{6}{|l|}{$\begin{array}{l}\text { 5. Translation courses enable me to master the } \\
\text { written components of a foreign language. }\end{array}$} \\
\hline $\begin{array}{l}\text { 6. Translation courses help improving my reading } \\
\text { and writing skills. }\end{array}$ & & & & & \\
\hline
\end{tabular}


7. Translation courses make an agreement between my needs and the aim of the courses I have.

8. Translation courses encourage my awareness of form and context.

\section{Four Language Skills}

1. Oral skills courses increase my listening and speaking capabilities.

2. Oral skills courses enable me to listen comprehensively to all the lectures given at the English department.

3. Oral skills courses give me the chance to speak about interesting literal texts.

4. Oral skills courses help me to communicate meaningfully in future career.

5. Oral skills courses give me the chance to promote creativity.

6. Writing courses are important in pursing my discipline.

7. Writing courses enhance my writing performance.

8. The research project course is beneficial for me in my future academic career.

9. Writing before, after and while reading makes me familiar with the text characteristics.

10. Extensive reading courses may have a significant positive effect on my writing performance.

11. Reading courses help me to achieve the learning outcomes in the EFL curriculum.

12. Reading and writing courses enhance my writing sub-skills such as (development, organization and language)

*What do you think of the courses you have had so far in the department?

* As an English language specialist, what do you think is the most useful courses?

* Why do you think that it is useful? (Feel free in your answer)

Appendix C

The most beneficial courses and the reasons for perceiving them this way

\begin{tabular}{|l|l|}
\multicolumn{1}{|c|}{$\begin{array}{c}\text { The most beneficial } \\
\text { courses }\end{array}$} & These courses introduce new ideas to me as a student \\
\hline Literature & Help me to learn new vocabulary \\
\hline Translation & improve my ability to speak \\
\hline oral skills & I can speak freely during the class \\
\hline oral skills & have learnt new vocabularies which I can use in my daily life \\
\hline Literature & enhance my skills \\
\hline oral courses & I use the four language skills during the class \\
\hline Translation & I love to speak in English \\
\hline oral skills & these are the skills students lack and also need to master the English language \\
\hline four skills & Interesting \\
\hline four skills & help me in my daily life \\
\hline oral skills & acquired me with the English accent \\
\hline Linguistics & improve my abilities and my personality \\
\hline Four lang skills & students are week in listening and speaking \\
\hline oral skills & improve our skills \\
\hline oral courses & \\
\hline
\end{tabular}




\begin{tabular}{|c|c|}
\hline $\begin{array}{c}\text { The most beneficial } \\
\text { courses }\end{array}$ & The reasons \\
\hline language skills & improve my language \\
\hline Writing & writing skills should be acquired \\
\hline Translation & Good \\
\hline Literature & enrich my words \\
\hline oral skills & help me in communicating with native speaking people \\
\hline four skills & empower my skills \\
\hline Translation & acquaint me with new vocabularies \\
\hline oral courses & enables me to communicate \\
\hline oral skills & develop my personality and my speaking skills \\
\hline oral skills & these skills are needed for my future career \\
\hline Four language skills & they are the bases of learning English \\
\hline oral skills & give me the ability to speak \\
\hline oral skills & important for my future \\
\hline Translation & enhance and improve my knowledge of new words \\
\hline Linguistics & These courses have improved my points of view of language \\
\hline Oral skills & They are needed for my future career \\
\hline Literature & have an influence on my real life \\
\hline Translation & help me in improving my reading and writing skills \\
\hline oral skills & to express my self \\
\hline Reading and writing & increased my vocabulary \\
\hline Writing & Important \\
\hline oral skills & enable me to communicate \\
\hline oral skills & I have the chance to speak in such courses \\
\hline Literature & provides me with new vocabulary \\
\hline Literature & It is interesting \\
\hline The language skills & The students have a roles in such courses \\
\hline Linguistics & introduce English language sounds to me \\
\hline Linguistics & help me in pronunciation \\
\hline Literature & has changed my way of thinking \\
\hline Reading and writing & improved my knowledge of the language \\
\hline Language skills & These courses enabled me to speak and write correctly \\
\hline Linguistics & teach me the bases of each field \\
\hline oral skills & the most important thing is to speak in English \\
\hline the four language skills & they have improved me \\
\hline four language skills & they are beneficial and improved my language \\
\hline Linguistics & this course is considered as the bases of all the language \\
\hline writing courses & improve my abilities \\
\hline oral skills & they are necessary for my future career \\
\hline Translation & help me a lot \\
\hline oral skills & We need to improve these courses \\
\hline reading and writing & help me to know more and to achieve my goals \\
\hline Literature & these courses are important \\
\hline language skills & I benefited from them in my daily life \\
\hline oral skills & good for communication with others \\
\hline oral skills & important for communication \\
\hline Translation & train and help me in understanding language aspects like grammar \\
\hline Linguistics & informed me about the language aspects \\
\hline oral skills & I can use them in my daily life \\
\hline Oral skills & help me in my daily life \\
\hline oral skills & improve my language \\
\hline Linguistics & introduce the sounds of language \\
\hline Writing & develop my writing and reading skills \\
\hline four language skills & develop my language \\
\hline Translation & improve my language knowledge \\
\hline
\end{tabular}




\begin{tabular}{|l|l|}
\hline \multicolumn{1}{|c|}{$\begin{array}{c}\text { The most beneficial } \\
\text { courses }\end{array}$} & The reasons \\
\hline oral skills & improve me \\
\hline the four language skills & I use them in my life \\
\hline Linguistics & acquaint me with language aspects \\
\hline literature courses & I learnt new vocabulary \\
\hline oral skills & improve my speaking skills \\
\hline reading and writing & increase my vocabulary \\
\hline Translation & help in learning new vocabularies \\
\hline language skills & easy to learn \\
\hline Translation & help in learning vocabulary \\
\hline oral skills & enable students to speak correctly and fluently and this help them in their future \\
\hline
\end{tabular}

Appendix D

The least beneficial courses and the reasons for perceiving them this way

\begin{tabular}{|c|c|}
\hline $\begin{array}{c}\text { The least } \\
\text { beneficial } \\
\text { courses }\end{array}$ & $x^{2}$ \\
\hline Linguistics & When are we supposed to use linguistics? \\
\hline Literature & all the class is for the professor \\
\hline Reading & not important \\
\hline Linguistics & can't use it outside the classroom \\
\hline Literature & not useful for my future career as a teacher \\
\hline Translation & it could be learnt without courses \\
\hline Literature & we don't communicate inside the class \\
\hline Linguistics & I don't use them in my daily life \\
\hline Sociolinguistics & logic related so not to be studied \\
\hline Literature & not related to my real life \\
\hline Linguistics & Useless \\
\hline Literature & there should be more focus on oral skills \\
\hline Linguistics & can be taught through other courses \\
\hline Linguistics & not important \\
\hline Reading & $\begin{array}{l}\text { In reading } 1 \text { course, students from different majors are mixed together, so this course is too } \\
\text { easy for an English major student and seen to be useless }\end{array}$ \\
\hline Linguistics & the course is not useful \\
\hline Linguistics & not used in the daily life \\
\hline Literature & the whole class is for the professor, we never have the chance to participate \\
\hline Linguistics & not important \\
\hline Literature & not important for me in the future if I become a teacher \\
\hline Linguistics & not important in our daily life \\
\hline Literature & not used in our daily life \\
\hline Literature & didn't benefit from them \\
\hline Linguistics & not important \\
\hline Literature & will not benefit us \\
\hline Literature & If I become a teacher, these courses will not be used \\
\hline Literature & don't help me in improving my English \\
\hline Linguistics & not important \\
\hline Literature & not important in our daily life \\
\hline Linguistics & not used in my daily life \\
\hline Literature & not accurate \\
\hline Linguistics & don't help in my daily life communication \\
\hline Reading & doesn't need separated courses \\
\hline Linguistics & not important \\
\hline Linguistics & there is no use of taking this course \\
\hline Linguistics & not used in my life \\
\hline Linguistics & didn't improve my skills \\
\hline Linguistics & they don't help us in learning language \\
\hline
\end{tabular}




\begin{tabular}{|c|c|}
\hline $\begin{array}{c}\text { The least } \\
\text { beneficial } \\
\text { courses }\end{array}$ & The reasons \\
\hline Linguistics & not important \\
\hline Linguistics & not important \\
\hline Linguistics & not important for my future career \\
\hline Linguistics & not helpful in our lives \\
\hline Linguistics & what is the use of taking the course \\
\hline Linguistics & not beneficial \\
\hline Translation & not suitable \\
\hline Linguistics & not important in our lives and difficult \\
\hline Linguistics & have nothing to do with literature \\
\hline Literature & these courses are important for me as a student, but will not help me in my future career \\
\hline Reading & don't improve our skills \\
\hline Literature & they are not applicable in our daily life \\
\hline Literature & there is no benefit from learning such courses \\
\hline Literature & didn't add anything to my skills \\
\hline Literature & don't give us the chance to express ourselves in writing \\
\hline Literature & not useful in using language 1 \\
\hline Reading & too easy \\
\hline Linguistics & not important in my daily life \\
\hline Translation & not given enough time \\
\hline $\begin{array}{l}\text { Four language } \\
\text { skills }\end{array}$ & didn't improve my skills as expected \\
\hline Literature & not used after college \\
\hline Literature & $\begin{array}{l}\text { Not important to know about the history of a culture. more important to know how to use } \\
\text { the language }\end{array}$ \\
\hline Literature & don't improve my skills \\
\hline Literature & not used in my daily life \\
\hline Linguistics & can't understand the importance of this course \\
\hline Linguistics & not useful in my daily life \\
\hline Linguistics & don't know the usefulness of such a course \\
\hline Literature & don't help in acquiring English \\
\hline Linguistics & there are much information to memories but don't know when and how to use them \\
\hline oral skills & don't provide us with information which could be used \\
\hline Linguistics & much information without application \\
\hline Literature & not important for communication \\
\hline Literature & don't get the chance to communicate \\
\hline Linguistics & not important for my future career \\
\hline Literature & not important for my future career \\
\hline Linguistics & they are not important \\
\hline linguistics & not important for my future career \\
\hline Literature & not used in the future \\
\hline Translation & can be acquired by ourselves without the need of courses \\
\hline Linguistics & not useful \\
\hline
\end{tabular}

